\title{
Energy Consumption and Economic Growth Nexus in China: Autoregressive Distributed Lag (ARDL)
}

\author{
Wan-Lin Yong \\ Faculty of Economics and Business, Universiti Malaysia Sarawak, 94300 Kota \\ Samarahan, Sarawak, Malaysia \\ Jerome Kueh (Corresponding author) \\ Faculty of Economics and Business, Universiti Malaysia Sarawak, 94300 Kota \\ Samarahan, Sarawak, Malaysia
}

Yong Sze Wei

Faculty of Business and Management, Universiti Teknologi MARA, 94300 Kota

Samarahan, Sarawak, Malaysia

Jang-Haw Tiang

Faculty of Economics and Business, Universiti Malaysia Sarawak, 94300 Kota

Samarahan, Sarawak, Malaysia

Received: April 22, 2020 Accepted: May 15, 2020 Online published: June 1, 2020

doi:10.5296/jpag.v10i2.16900

URL: https://doi.org/10.5296/jpag.v10i2.16900

\begin{abstract}
This paper intends to investigate the nexus between energy consumption, carbon dioxide emission, total export and economic growth of China from 1971 to 2014. This study adopted Autoregressive Distributed Lag (ARDL) bounds test to examine the existence of short-run and long-run relationships among the variables. Empirical findings indicated that energy consumption contribute to economic growth while carbon dioxide emission is impeding the growth. There is a positive long-run relationship between both energy consumption and total export with economic growth of China. However, a negative relationship is observed between carbon dioxide emissions and economic growth. Hence, in terms of policy recommendation, policymakers can implement a balance environment-economic policy; reduce the carbon
\end{abstract}


dioxide emission by imposing carbon tax; promote renewable energy among the industries and households and promoting reserves forest policy is needed for aspiration of sustainable growth for both environmental and economic.

Keywords: energy consumption, carbon dioxide emission, autoregressive distributed lag

\section{Introduction}

The environmental crisis is a worldwide ongoing concern for all the countries since 1970s. Issues that associated with the environmental crisis are not only the environmental problem, but it can be related to the economic, social, and technological issues. The main features of the environmental crisis such as climate change, the depletion of stratospheric ozone, degraded air and water quality, deforestation, and soil erosion and degradation will affect the quality of the environmental and the health of life-being. In addition, the environmental crisis that related to economic such as increase in the number of populations rapidly, urbanisation and peak oil and energy security will also bring negative impact to environment. Hence, the environmental crisis had become the biggest challenge to all countries and the government need to work out the best solution in order to tackle environment issues.

China, the world largest developing economies have experienced an average 7.1 per cent growth over the past half-decade. Although the rapid increase in economic growth, its environmental crisis is getting worst. Based on the data released by World Development Indicators (WDI), the total consumption of energy ( $\mathrm{kg}$ of oil equivalent per capita) of China experiencing rapid increase almost $381.09 \%$ from $464.93 \mathrm{~kg}$ to $2236.73 \mathrm{~kg}$ from 1971 to 2014 (refer to Figure 2). Moreover, air pollution that caused by the increasing amount of carbon dioxide emission critically affects the environmental problem in China. The carbon dioxide emission in China has risen dramatically over a half-century (refer to Figure 3). According to Hays (2015), the increase in carbon dioxide emission is mostly caused by energy consumption such as coal consumption which major used for power generation in the industry field. In addition, China is the top coal and lignite consumption consumers worldwide exceed with India and the United States (Enerdata, 2018).

The surplus of carbon emission emissions will contribute to the greenhouse effect in China and cause the environmental crisis which eventually affects the health of the citizen. From the microeconomic perspective, the rapid increase in total exports can contribute to the environmental crises. In the sense that, growing on production for goods to sustain the market demand leading an increasing energy consumption for production needs which eventually it contributed on the emission of air pollutant that affects the environment and living things. A rapid increase in both emissions of carbon dioxide and energy consumption become the main issues that need to be a concern by policy-makers.

However, energy consumption and GDP do not have any clear-cut decision. Some of the research that investigated the energy consumption, emission of carbon dioxide and economic growth had come out with different views. The findings from those researches are controversial in both theory and empirical. Hence, the purpose of this study is to empirical determine the impact of energy consumption on the economic growth of China by also 


\section{Macrothink}

considering the role of carbon dioxide emission. In addition, understanding the relationships of energy consumption is critical to the policy makers as it provides significant guideline regarding achieving an ecological-economic balance and both sustainable developments. The remaining of the study is organized as follows: Section 2 describes literature review; Section 3 presents the data and methodology: Section 4 provides the results and discussions and Section 5 provides the conclusion and policy recommendation.

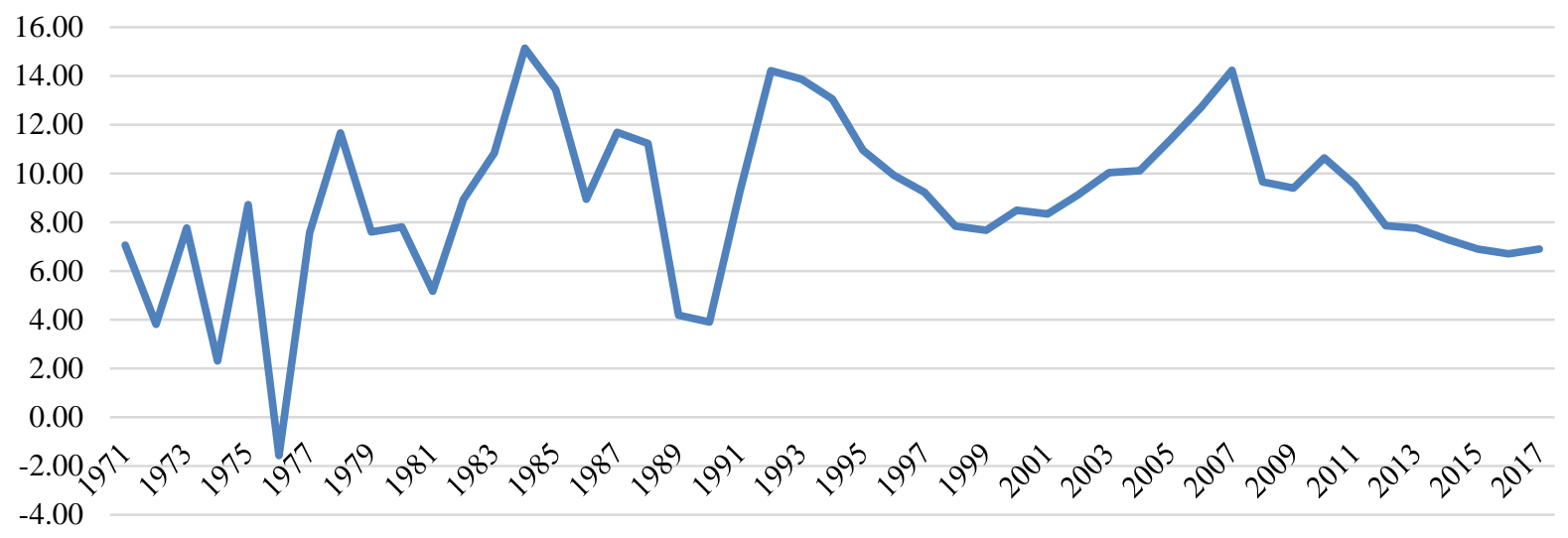

Figure 1. Gross Domestic Product (GDP) Growth rate (\%) of China from 1971 to 2017

Sources: Adapted and modified from World Development Indicators (WDI) published by World Bank.

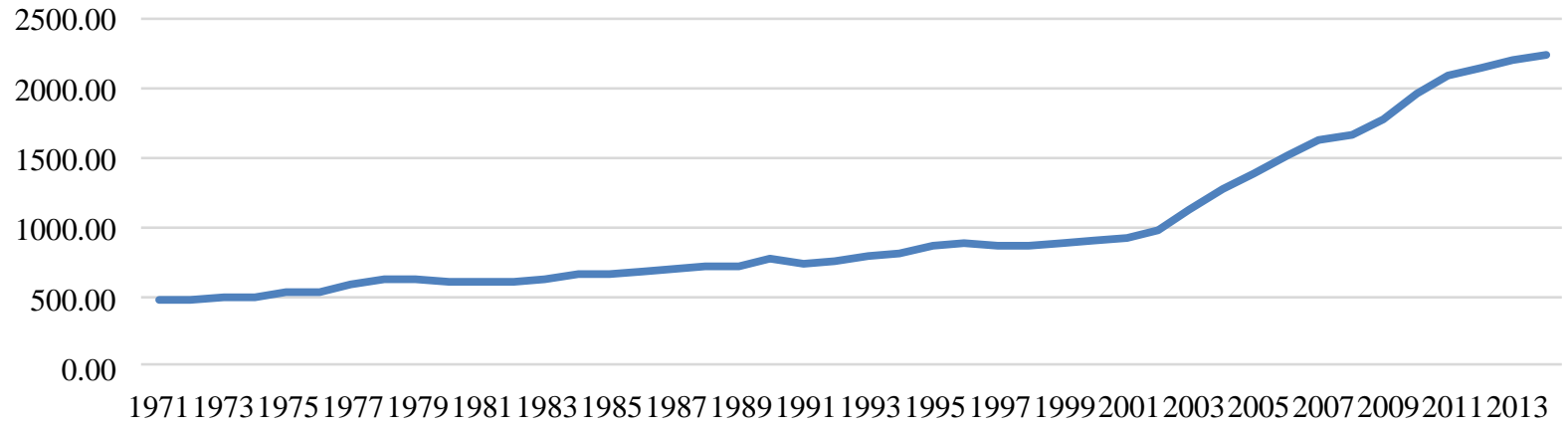

Figure 2. Energy Consumption (kg of oil equivalent per capita) of China from 1971 to 2014

Sources: Adapted and modified from World Development Indicators (WDI) published by World Bank. 


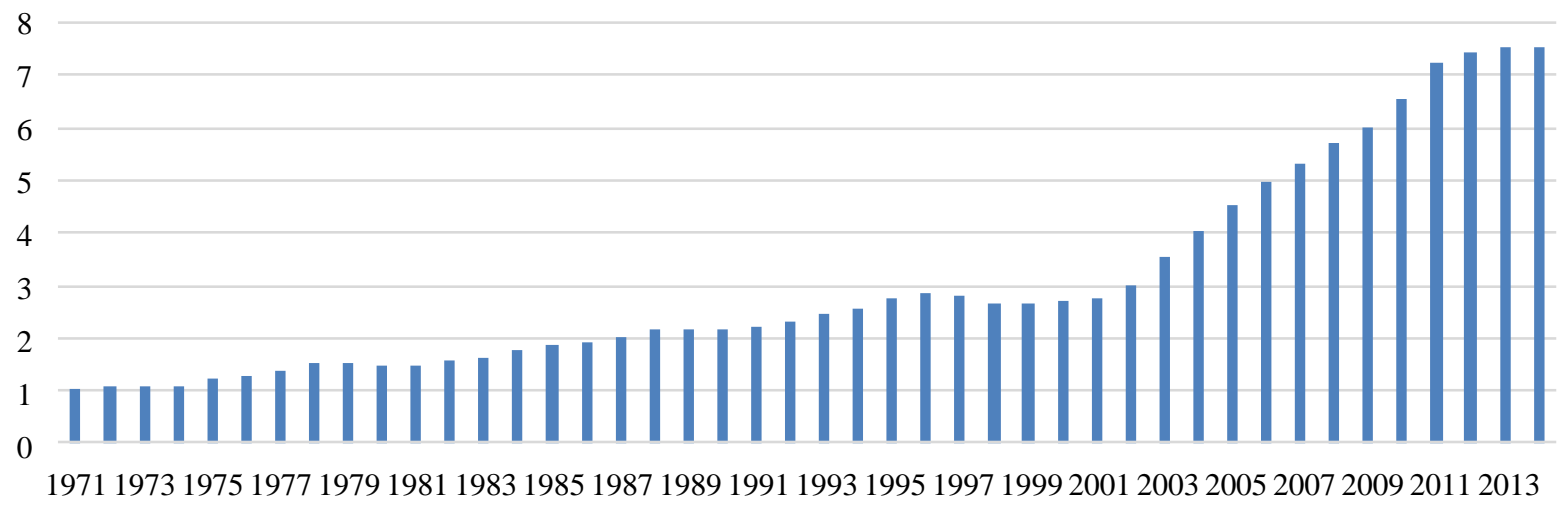

Figure 3. Carbon Dioxide Emissions (metric tons per capita) of China from 1971 to 2014

Sources: Adapted and modified from World Development Indicators (WDI) published by World Bank.

\section{Literature Review}

The are many studies been conducted to determine the nexus between energy consumption growth and economic growth. However, it should worth to noted that the studies differ from each other from the aspect of the country, methodology, the time frame of studies, the selection of variables. In this section, the selected studies are comprehensively summarized in the paragraph following.

The rapid growth of the economy can contribute the different impact to the environmental. For instance, rising in consumption of energy to the certain extent would stimulate economic growth. Conversely, it can cause the increase of carbon dioxide emission which affects the environment quality. Several studies from the researchers stated that there is the existence of bidirectional causality between total energy consumption and GDP. (see for examples, Alper et al., 2013; Belke et al., 2011; Lee \& Chang, 2005; Shahbaz et al., 2014; Shahbaz, Khan \& Tahir, 2013; Shahbaz \& Lean, 2012; Shahbaz, Zeshan \& Afza, 2012; Tiwari et al., 2013; Yang, 2000). The panel study conducted by Ayeche et al. (2016) and Antonakakis et al. (2017) have also discovered a similar result. In contrast, Apergis \& Payne (2010) found out that energy consumption only had unidirectional causality relationship with GDP both in the short-run and long-run based on VECM results. Conversely, Vlahinić-Dizdarević \& Žiković (2010) and Shahbaz et al. (2014) stated that economic growth unidirectional granger cause to energy consumption. Interestingly, Ozturk \& Acaravci (2010) and Shahbaz, Khan, and Tahir (2013) argue that there is no relationship between energy consumption and GDP. The results are clearly inconclusive and ambiguous.

Moreover, carbon dioxide emission can give impact to the economic growth and energy consumption. The panel study conducted by Al-Mulali et al. (2015) has stated that GDP is one of the main contributions to carbon dioxide emissions. According to Lean \& Smyth (2010a), a positive relationship showed between energy consumption and carbon dioxide emissions and the carbon dioxide is unidirectional Granger cause to economic growth. Moreover, same results also have also been discovered by Tiwari (2011) who stated a positive 
relationship between energy consumption and carbon dioxide emissions while he also stated that carbon dioxide emission showed the negative impact to the GDP. An early study in China done by Cui (2016) had observed a linear relationship exist between economic growth, carbon dioxide emissions, and energy consumption whilst international trade give a significant impact on carbon dioxide emission.

A perspective stated the when total export increase, it will cause the increase in carbon dioxide emission. According to Tiwari et al. (2013) assert that a positive relationship showed between trade openness and carbon dioxide emissions. However, Al-Mulali et al. (2015) argue that trade openness had a negative relationship between carbon dioxide emissions. This is because trade openness belongs to the non-polluted industries. Hence, an argument between the relationship between total exports and carbon dioxide is formed in the literature overview.

Overall studies are employing the time series data to capture the trend of the economy (see for examples, Cui, 2016; Lee \& Chang, 2005; Lean \&Smyth, 2010b; Lean \& Smyth, 2010c; Narayan \& Smyth, 2005; Ozturk \& Acaravci, 2010; Payne, 2009; Shahbaz \& Lean, 2012; Shahbaz, Lean \& Farooq, 2012; Shahbaz, Lean \& Shabbir, 2011; Shahbaz, Khan, \& Tahir, 2013; Shahbaz, Zeshan \& Afza, 2012; Shahbaz et al., 2014; Shahbaz, Tang \& Shabbir, 2011; Tiwari, 2011; Tiwari et al., 2013; Vlahinić-Dizdarević \& Žiković, 2010; Yang, 2000). However, some studies have been using the panel analysis, which includes various countries with a timeframe of more than 5 years (see for examples, Al-Mulali et al., 2015; Antonakakis et al., 2017; Apergis \& Payne, 2010; Alper et al., 2013; Ayeche et al., 2016; Belke et al., 2011; Işı1k \& Shahbaz, 2015; Lean \& Smyth, 2010a; Lotz, 2016; Soytas \& Sari, 2003; Ucan et al., 2014). In this case, time series data analysis shows a very effective method of forecasting due to the make use of the seasoned patterns, while panel data is more effective in collecting the data of those different countries with same variables for an amount of time.

Although there is a considerable amount of study investigate the relationship between energy consumption, carbon dioxide emissions, and economic growth. In overall, inconclusive results and arguments for energy consumption and economic growth are very much to study in order to verify the actual relationships, particularly for China. This study expected to provide new evidence link of energy consumption and economic growth. This aims to verify the validity of the association of energy consumption, carbon dioxide emissions, total export and economic growth of China.

\section{Data and Methodology}

This empirical analysis utilizes annually data from the period from 1971 to 2014. The investigation on the relationships on energy consumption, carbon dioxide emission, total export and economic growth of China is undertaken by unit root tests, autoregressive distributed lag (ARDL) bounds testing approach to cointegration and follow with the several diagnostic testing procedures. All variables are obtained from World Development Indicators (WDI) published by World Bank.

Let GDP denote real gross domestic product per capita (US\$); EC denotes the energy 
consumption measure in $\mathrm{kg}$ of oil equivalent per capita; $C O$ denotes carbon dioxide emission measured in per capita in metric tons; $T E$ denotes the total export (US\$ billon). The estimation models are specified as follow:

$$
\ln G D P_{t}=\beta_{0}+\beta_{1} \ln E C_{t}+\beta_{2} \ln C O_{t}+\beta_{3} \ln T E_{t}+\varepsilon_{t}
$$

\section{Augmented Dickey-Fuller (ADF) Unit Root Test}

Augmented Dickey-Fuller (ADF) (1979) unit root test is used to examine the properties of the time series as shown in Equation (2).

$$
\Delta Y_{t}=\beta_{0}+\beta_{1} t+\gamma_{1} Y_{t-1}+\sum \gamma_{2 j} \Delta Y_{t-j}+\varepsilon_{t}
$$

where $Y_{t}$ is variable of interest, $\Delta$ is to differencing operator, $t$ is to time trend and $\varepsilon$ is to the error term. $\beta_{0}, \beta_{1}, \gamma_{1}$ and $\gamma_{2 j}$ are parameters to be estimated where the null and alternative hypotheses are as followed:

$$
\begin{aligned}
& H_{0}: \gamma_{1} \geq 0 \\
& H_{\mathbb{a}}: y_{1}<0
\end{aligned}
$$

The decision rule of the stationarity is when the null hypothesis cannot be rejected, $Y_{t}$ has a unit root or non-stationary. Instead, when the null hypothesis can be rejected, $Y_{t}$ is stationary. On the other words, When the value of computed test statistic is larger than the critical value at a significance level, the null hypothesis for ADF test can be rejected. This show that the variable is stationary and integrated at the corresponding orders, whether it is in first different or level form. In others hand, do not reject the null hypothesis when the value of the computed test statistic is smaller than the critical value at a significant level. This indicates that the variable is non-stationary and has a unit root. When it has a unit root in the first order, then the first different order will make the stationary.

\section{Phillips-Perron (PP) Unit Root Test}

In order to assure the solidity of the unit root test, this study also incorporated Phillips and Perron (PP) (1988) unit root test. The different between Phillips-Perron (PP) Test and ADF test is how it deals with serial correlation and heteroscedasticity in the errors. In the test of regression, PP tests ignore any serial correlation that occurs. PP has test regression as follow:

$$
\Delta y_{t}=\beta^{\prime} \mathrm{D}_{t}+\pi y_{t-1}+\mu_{t}
$$


where $\mu_{t}$ is $I(0)$ and may be heteroscedasticity. The PP tests will modify the test statistic $t_{n}=0$ and $T_{\pi}$ to correct the serial correlation and heteroscedasticity in the errors $\mu_{t}$.

\section{Kwiatkowski Phillips Schmidt Shin (KPSS) Unit Root Test}

KPSS test had been developed at 1992. This test is different from others unit root test which the null hypothesis of this test is opposite with others unit root test such as ADF test and PP test. KPSS test is based on residuals from OLS regression, the LM statistic is defined as follow:

$$
L M=\sum_{t} \frac{S(t)^{2}}{\left(T^{2} f_{0}\right)}
$$

where $f_{0}$ is an estimator of the residual spectrum at frequency zero and where $S(t)$ is a cumulative residual function.

\section{Autoregressive Distributed Lag (ARDL) Bounds Testing Approach to Cointegration}

The ARDL bounds testing approach to co-integration is developed by Pesaran et al. (2001) to explore the existence of long-run equilibrium among the series. The ARDL bounds testing approach has several advantages compare to Engle \& Granger and Johansen and Juselius procedures which (1) all the variables do not need to be of equal order of integration in the system; (2) it is an efficient estimator even if samples are small and some of the regressors are endogenous; (3) it allows the variables may have different optimal lags; and (4) it employs a single reduced from equation.

There are two steps that involve in ARDL bounds testing in order to estimate the long-run relationship. The first step is to investigate the existence of long-run relationship between all the variables in the equation. The ARDL model for the long-run relationship between energy consumption per capita, carbon dioxide per capita, total exports, population and GDP per capita may follows as:

$$
\begin{aligned}
& \Delta \ln G D P_{t} \\
& =\alpha_{1}+\sum_{i=1}^{p} \beta_{1 i} \Delta \ln G D P_{t-i}+\sum_{j=0}^{q} \emptyset_{1 j} \Delta \ln E C_{t-j}+\sum_{k=0}^{r} \varphi_{1 k} \Delta \ln C O_{t-p}+\sum_{l=0}^{s} \theta_{1 i} \Delta \ln T E_{t-l} \\
& +\alpha_{G D P} \ln G D P_{t-1}+\alpha_{E C} \ln E C_{t-1}+\alpha_{C o} \ln C O_{t-1}+\alpha_{T E} \ln T E_{t-1} \\
& +\varepsilon_{1 t}
\end{aligned}
$$

Where $\Delta$ is the first difference operator and $\varepsilon_{t}$ is the error term. Based on Akaike Information Criteria (AIC), the optimal lag structure of the first difference regression is selected. The lag is induced when noise in the error term. $F$-test is suggested for joint significance of the coefficients of the lagged level of the variables (Pesaran et al., 2001). For example, the null hypothesis of no long-run relationship between the variables in Equation (2) 
is:

$$
\begin{aligned}
& H_{0}: \alpha G D P=\alpha E C=\alpha C O=\alpha T E=0 \\
& H_{a}: \alpha G D P \neq \alpha E C \neq \alpha C O \neq \alpha T E \neq 0
\end{aligned}
$$

Two asymptotic critical bounds are used to test for co-integrations. If the order of integration for all the series is $I(0)_{\text {, }}$ the lower bound is applied and the decision is made based on lower bound while if all series are $I(1)$, then the upper bound is used and the decision is made based on the upper bound. The favour of long-run relationship is occurred if the $F$-statistic exceeds the upper critical value while the null hypothesis of no co-integration cannot be rejected if the $F$-statistic falls below the lower critical value. However, the inference is inconclusive if the $F$-statistic lies between the two bounds. The second step is to estimate the long-run and short-run models that represented in Equation (6) and Equation (7) if there is evidence of co-integration (long-run relationship) between these variables.

$\ln G D P_{t}$

$=\alpha_{2}+\sum_{i=1}^{p} \beta_{2 i} \ln G D P_{t-i}+\sum_{j=0}^{q} \emptyset_{2 j} \ln E C_{t-j}+\sum_{k=0}^{r} \varphi_{2 k} \ln C O_{t-p}+\sum_{l=0}^{s} \theta_{2 l} \ln T E_{t-l}$

$+\varepsilon_{2 t}$

$$
\begin{aligned}
& \Delta l n G D P_{t}= \alpha_{3} \\
&+\sum_{i=1}^{p} \beta_{3 i} \Delta l n G D P_{t-i}+\sum_{j=0}^{q} \emptyset_{3 j} \Delta \ln E C_{t-j}+\sum_{k=0}^{r} \varphi_{3 k} \Delta \operatorname{lnCO_{2t-p}} \\
&+\sum_{l=0}^{s} \theta_{3 l} \ln T E_{t-l}+\gamma E C M_{t-1} \\
&+\varepsilon_{3 t}
\end{aligned}
$$

where $\gamma$ is the coefficient of error correction term. $E C M_{t}$ is defined as:

$$
\begin{aligned}
& E C M_{t} \\
& =\ln G D P_{t}-\alpha_{2}-\sum_{i=1}^{p} \beta_{2 i} \ln G D P_{t-i}-\sum_{j=0}^{q} \emptyset_{2 j} \ln E C_{t-j}-\sum_{k=0}^{r} \varphi_{2 k} \ln C O_{2 t-p} \\
& -\sum_{l=0}^{s} \theta_{2 l} \ln T E_{t-l}
\end{aligned}
$$

It shows how quickly variables converge to equilibrium and it should have a statistically significant coefficient with a negative sign. 


\section{Results and Discussion}

In the light of methodology presented above, the empirical results are discussed in this section. Table 1 presented the unit root test results based on Augmented Dickey-Fuller (ADF), Phillips-Perron (PP), and Kwiatkowski Phillips Schmidt Shin (KPSS). For the ADF and PP, all the time series variables are non-stationary at the level since the null hypothesis cannot be rejected. But the null hypothesis can be rejected after proceeds to the first difference which means all the time series are stationary after the first difference. Conversely, the null hypothesis for the KPSS test is the time series is stationary is rejected at the level. Hence the time series is found to be stationary after proceeds to first difference. Overall unit roots tests confirm all the time series is stationary at the first level or integrated with the same order.

Table 1. Result of ADF, PP and KPSS Unit Root Test Results

\begin{tabular}{|c|c|c|c|c|c|c|}
\hline Variables & \multicolumn{2}{|c|}{ ADF } & \multicolumn{2}{|c|}{$\mathbf{P P}$} & \multicolumn{2}{|c|}{ KPSS } \\
\hline \multicolumn{7}{|c|}{ Level } \\
\hline & $t_{u}$ & $t_{t}$ & $T_{u}$ & $T_{t}$ & $\eta_{u}$ & $\eta_{t}$ \\
\hline$L G D P_{t}$ & $\begin{array}{c}2.1821 \\
{[0.9999]}\end{array}$ & $\begin{array}{c}-0.7827 \\
{[0.9592]}\end{array}$ & $\begin{array}{c}2.4013 \\
{[1.0000]}\end{array}$ & $\begin{array}{l}-0.6045 \\
{[0.9736]}\end{array}$ & $0.8215^{* *}$ & $0.2103 * *$ \\
\hline$L E C_{t}$ & $\begin{array}{c}0.6430 \\
{[0.9893]}\end{array}$ & $\begin{array}{c}-1.3500 \\
{[0.8610]}\end{array}$ & $\begin{array}{c}1.3387 \\
{[0.9985]}\end{array}$ & $\begin{array}{c}-0.8771 \\
{[0.9494]}\end{array}$ & $0.7925 * *$ & $0.1855^{* *}$ \\
\hline $\mathrm{LCO}_{t}$ & $\begin{array}{c}1.009 \\
{[0.9959]}\end{array}$ & $\begin{array}{c}-1.5998 \\
{[0.7748]}\end{array}$ & $\begin{array}{c}0.4731 \\
{[0.9838]}\end{array}$ & $\begin{array}{c}-1.5660 \\
{[0.7899]}\end{array}$ & $0.8156^{* *}$ & $0.1484 * *$ \\
\hline$L T P_{t}$ & $\begin{array}{c}-0.5416 \\
{[0.8727]}\end{array}$ & $\begin{array}{c}-2.5295 \\
{[0.3132]}\end{array}$ & $\begin{array}{c}-0.5359 \\
{[0.8739]}\end{array}$ & $\begin{array}{c}-2.5295 \\
{[0.3132]}\end{array}$ & $0.8408 * *$ & $0.1627 * *$ \\
\hline \multicolumn{7}{|c|}{ First Difference } \\
\hline$\Delta L G D P_{t}$ & $\begin{array}{c}t_{u} \\
-5.2656^{* *} \\
{[0.0001]}\end{array}$ & $\begin{array}{c}t_{t} \\
-6.1126^{* *} \\
{[0.0000]}\end{array}$ & $\begin{array}{c}T_{u} \\
-5.3124^{* *} \\
{[0.0001]}\end{array}$ & $\begin{array}{c}T_{t} \\
-6.1186^{* *} \\
{[0.0000]}\end{array}$ & $\begin{array}{c}\eta_{u} \\
0.5032 * *\end{array}$ & $\begin{array}{c}\eta_{t} \\
0.0623\end{array}$ \\
\hline$\Delta \boldsymbol{L E} \boldsymbol{C}_{t}$ & $\begin{array}{c}-3.5655^{* *} \\
{[0.0108]}\end{array}$ & $\begin{array}{c}-3.7419 * * \\
{[0.0302]}\end{array}$ & $\begin{array}{c}-3.5698 * * \\
{[0.0107]}\end{array}$ & $\begin{array}{c}-3.7255 * * \\
{[0.0314]}\end{array}$ & 0.3143 & 0.0820 \\
\hline$\Delta \mathrm{LCO}_{t}$ & $\begin{array}{c}-3.4699 * * \\
{[0.0143]}\end{array}$ & $\begin{array}{c}-3.7667 * * \\
{[0.0294]}\end{array}$ & $\begin{array}{c}-3.4849 * * \\
{[0.0133]}\end{array}$ & $\begin{array}{l}-3.4620 \\
{[0.0569]}\end{array}$ & 0.1411 & 0.0619 \\
\hline$\Delta L T E_{t}$ & $\begin{array}{c}-5.5848 * * \\
{[0.0000]}\end{array}$ & $\begin{array}{c}-5.5149 * * \\
{[0.0003]}\end{array}$ & $\begin{array}{c}-5.5398 * * \\
{[0.0000]}\end{array}$ & $\begin{array}{c}-5.4655^{* *} * \\
{[0.0003]}\end{array}$ & 0.0469 & 0.0459 \\
\hline
\end{tabular}

Notes: The $t, T$, and ${ }^{\eta}$ statistics are for ADF, DFGLS and KPSS respectively. The subscript

$u$ in the model allows a drift term while ${ }^{t}$ allows for a drift and deterministic trend. Refer to the main text for the notations. $L G D P=$ logarithm GDP, $L E C=$ logarithm energy consumption, $L C O=$ logarithm carbon dioxide emission, and $L T E=$ total export. $\Delta$ is the first difference operator. Number in brackets [ ] are represent the p-value of the variable. ** denotes rejection of the null at 5\% significant level. Optimal lag is selected based on Schwarz Info Criterion (SIC).

By having confirmed stationary for all the time series. The subsequent step is to check the possibility of long-run equilibrium relationship between the LGDP, LEC, LCO, and LTE. Table 2a shows the results of Autoregressive Distributed Lag (ARDL) Bounds Testing Approach. Table $2 \mathrm{~b}$ indicated the short-run and long-run results. Akaike information criterion (AIC) is used to select the lag length for the ARDL bounds testing approach to cointegration. 
From the Table $2 \mathrm{a}$, the $F$-statistics of $L G D P_{\mathrm{t}}$ for three models is greater than three of the $I(1)$ bound values. Hence, there are cointegration vectors in three of the models when $L G D P_{t}$ is used as the dependent variables. In Table $2 b$, based on the bound $F$-test which use to test for cointegration test, it provides the evidence of a long-run relationship exist for three models at $5 \%$ significance level in China.

In the Model 1, the estimated long-run coefficient of $L E C_{t}$ is 4.5910 is statistically significant and having a positive sign, which means that when $1 \%$ increase in energy consumption will also increase GDP by $4.59 \%$. Conversely, there is no short-run relationship between energy consumption and economic growth. In the Model 2, the estimated long-run coefficient of $L E C_{t}$ is $3.1310, L C O_{t}$ is -1.6965 and $L T E_{t_{\mathrm{t}}}$ is 0.5126 . This implies that $1 \%$ increase in energy consumption, increase GDP by $3.13 \%$. Besides that, when $1 \%$ increase in carbon dioxide emission per capita, decrease GDP by $1.70 \%$. And, an increase of $1 \%$ in total export will increase GDP by $0.51 \%$. In the Model 3, the energy consumption and total export have a long-run relationship with GDP except for carbon dioxide emission. Meanwhile, carbon dioxide emission and total exports are significant at short-run. The long-run results revealed $1 \%$ increase in energy consumption and total export will increase GDP by $2.81 \%$. and $0.51 \%$ respectively. Crisis variables represent the economic crisis that occur between the study periods. The coefficient of crisis variable is 0.6040 which mean that when economic crisis occurs, it will cause the GDP increase approximately $0.60 \%$. On the other hand, the short-run results show the $1 \%$ increase in carbon dioxide emission will decrease GDP by $0.16 \%$. Conversely, a $1 \%$ increase in total export will increase GDP by $0.14 \%$.

Moreover, the result of lag error term $E C M_{t-1}$ show the existence of long-run relationship among the variables when it has negative sign and significant at 5 percent of significance level. Three models have fulfil the requirement of $E C M_{t-1}$. In Model 1, the estimated coefficient of -0.0606 which means is about 6.06 percent per year. It will take about 16.5 years to adjust the long-run equilibrium due to short-run equilibrium. In the Model 2, the estimated coefficient is -0.3306 which is about 33.06 percent per year. It will take about 3.02 years to adjust the long-run equilibrium due to the short-run equilibrium. In Model 3, the estimated coefficient is -0.3191 which is about 31.91 percent per year and will take about 3.13 years to adjust the long-run equilibrium due to short-run equilibrium. In overall, Model 2 showed that the time period that use to adjust the long-run equilibrium is shorter than the other two models.

In addition, the diagnostic tests for Model 1 had confirmed the error term is normally distributed, there is no any autoregressive conditional heteroscedasticity and serial correlation is no occur in this model. Furthermore, the ARDL model is stable which the blue line of CUSUM and CUSUMSQ fluctuates within the range of $5 \%$ significance level (refer to the Figure 4). However, Ramsey RESET test shows that the functional form of the model is not 
specified.

The diagnostic test for Model 2 and Model 3 also found out a similar result. The error term is normally distributed, there is no any autoregressive conditional heteroscedasticity and serial correlation. The ARDL model is stable which the blue line of CUSUM and CUSUMSQ fluctuates within the range of 5 percent significance level (refer to the Figure 5 and Figure 6 ) and Ramsey RESET test shows that the functional form of the model is specified for both models.

Table 2a. ARDL Cointegration Test Result

\begin{tabular}{|c|c|c|c|}
\hline Variable & Model 1 & Model 2 & Model 3 \\
\hline Optimal lag & $(1,4)$ & $(3,4,0,0)$ & $(3,4,4,3,4)$ \\
\hline$F$-statistics & $6.3325 * * *$ & $5.5009 * * *$ & $7.7041 * *$ \\
\hline $\begin{array}{l}\text { Lower } \\
I(0)\end{array}$ & bounds & & \\
\hline 1 percent & 4.94 & 3.65 & 3.29 \\
\hline 5 percent & 3.62 & 2.79 & 2.56 \\
\hline 10 percent & 3.02 & 2.37 & 2.2 \\
\hline $\begin{array}{l}\text { Upper } \\
I(1)\end{array}$ & bounds & & \\
\hline 1 percent & 5.58 & 4.66 & 4.37 \\
\hline 5 percent & 4.16 & 3.67 & 3.49 \\
\hline 10 percent & 3.51 & 3.0 & 3.09 \\
\hline $\mathrm{R}^{2}$ & 0.4189 & 0.0628 & 0.6624 \\
\hline Adj- $R^{2}$ & 0.3132 & 0.4998 & 0.5298 \\
\hline$F$-statistics & $3.9645^{* * *}$ & $4.8973 * * *$ & $4.9944 * *$ \\
\hline
\end{tabular}

Notes: Asterisks *,** and $* * *$ denote the significance at $10 \%, 5 \%$ and $1 \%$ level respectively. The optimal lag structure is determined by Akaike information criterion (AIC).

Table 2b. Long-run and Short-run Result

\begin{tabular}{llll}
\hline $\begin{array}{l}\text { Dependent variable: } \text { LGDP }_{\boldsymbol{t}} \\
\text { Long-run results }\end{array}$ & \multicolumn{1}{c}{ Model 1 } & \multicolumn{1}{c}{ Model 2 } & \multicolumn{1}{c}{ Model 3 } \\
\hline Variables & -2.1446 & -5.1245 & -3.0951 \\
Constant & {$[-0.2309]$} & {$[-0.9296]$} & {$[-0.5747]$} \\
& $(0.8188)$ & $(0.3603)$ & $(0.5701)$ \\
LEC $_{\mathbf{t}}$ & $4.5910^{* *}$ & $3.1310^{* *}$ & $2.8073^{* *}$ \\
& {$[2.8654]$} & {$[4.2235]$} & {$[3.9264]$} \\
LCO $_{\mathbf{t}}$ & $(0.0072)$ & $(0.0002)$ & $(0.0007)$ \\
& - & $-1.6965^{* *}$ & -1.3820 \\
LTE $_{\mathbf{t}}$ & & {$[-2.2066]$} & {$[-1.8453]$} \\
& - & $(0.0354)$ & $(0.0756)$ \\
& & $0.5126^{* *}$ & $0.5095^{* *}$ \\
& & {$[5.1707]$} & {$[5.3225]$}
\end{tabular}


Crisis

$(0.0000)$

$(0.0000)$

$0.6040 * *$

$[-2.2372]$

$(0.0334)$

\begin{tabular}{llll}
\hline Short-run results & \multicolumn{1}{c}{ Model 2 } & \multicolumn{1}{c}{ Model 3 } \\
\hline Variables & \multicolumn{1}{c}{ Model 1 } & 0.3810 & 0.7934 \\
LEC $_{\mathbf{t}}$ & 0.2350 & {$[0.7834]$} & {$[0.1616]$} \\
& {$[0.6837]$} & $(0.4398)$ & $(0.8728)$ \\
LCO $_{\mathbf{t}}$ & $(0.4989)$ & -0.3273 & $-0.1629^{* *}$ \\
& - & {$[-0.8039]$} & {$[-4.0064]$} \\
LTE $_{\mathbf{t}}$ & - & $(0.4280)$ & $(0.0004)$ \\
& & 0.1397 & $0.1435^{* *}$ \\
Crisis & & {$[1.8397]$} & {$[2.1512]$} \\
& - & $(0.0761)$ & $(0.0402)$ \\
ECM & & -0.0489 \\
& & & {$[1.3228]$} \\
Diagnostic Test & $-0.0606^{* * *}$ & $-0.3306^{* *}$ & $(0.1966)$ \\
$\chi^{2}$ NORMAL & {$[-4.4888]$} & {$[-4.3023]$} & $-0.3194 * *$ \\
& $(0.0001)$ & $(0.0002)$ & {$[-6.2253]$} \\
$\chi^{2}$ SERIAL & & & $(0.0000)$ \\
$\chi^{2}$ WHITE & 0.6802 & 0.1694 & 0.4049 \\
$\chi^{2}$ RAMSAY & $(0.7117)$ & $(0.9188)$ & $(0.8167)$ \\
& 0.7573 & 0.5298 & 0.0998 \\
& $(0.4774)$ & $(0.5947)$ & $(0.9053)$ \\
& 1.4284 & 1.2259 & 1.5576 \\
& $(0.2335)$ & $(0.3163)$ & $(0.8459)$ \\
& 2.5270 & 0.9755 & 1.0944 \\
& $(0.0166) * *$ & $(0.3318)$ & $(0.3048)$ \\
\hline
\end{tabular}

Notes: Asterisks ** shows the significance at 5 percent level. [ ] represent the t-statistic of the variable and ( ) represent the p-value of the variable. Model 1 consists of LGDPt and LECt; Model 2 consists of LGDPt, LECt, LCOt, and LTEt; Model 3 consists of LGDPt, LECt, LCOt, $L T E t$ and Crisis variable.

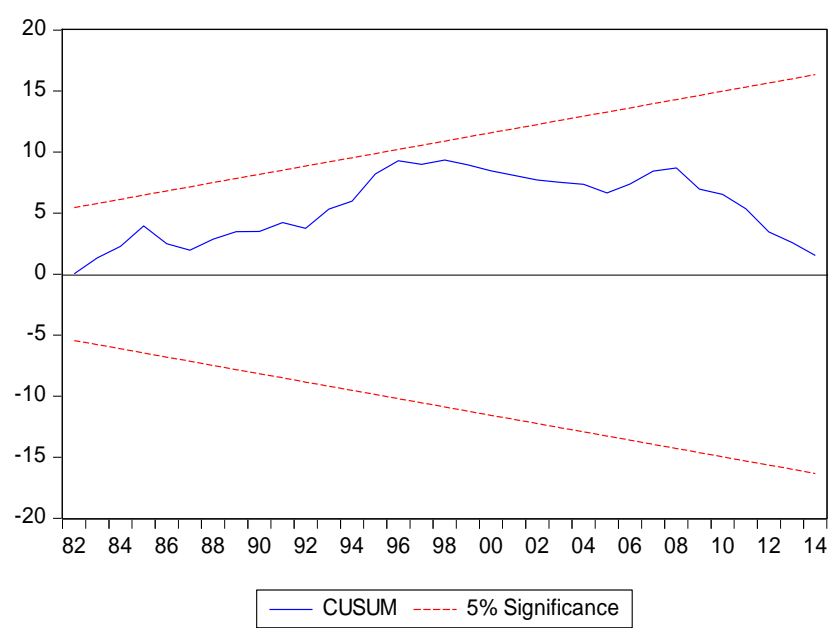




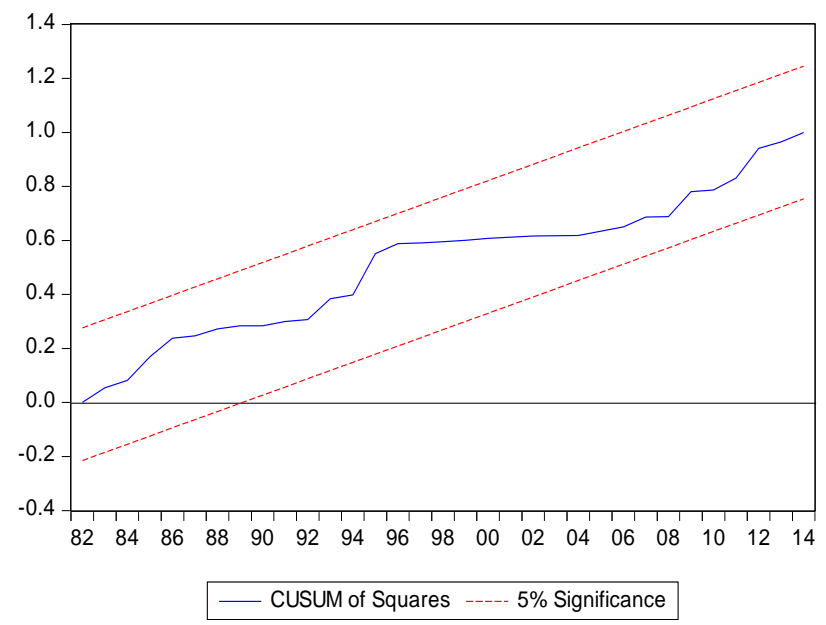

Figure 4. Plot of CUSUM and CUSUM of Square of Model 1

Note: The straight lines represent critical bounds at 5\% significance level.

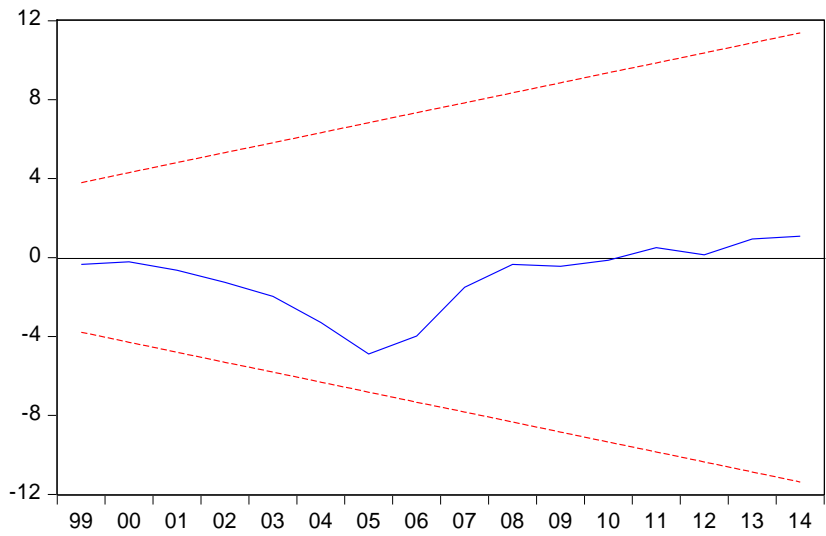

- CUSUM ---- 5\% Significance

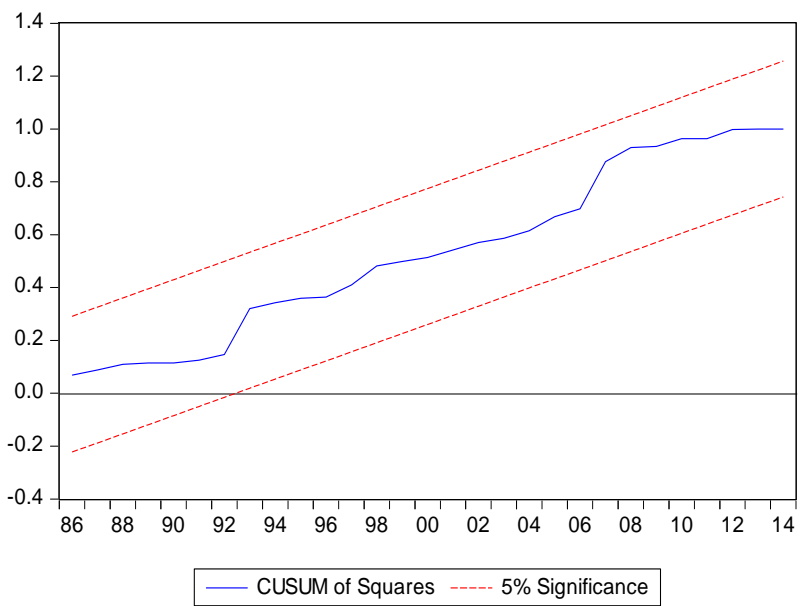

Figure 5. Plot of CUSUM and CUSUM Square of Model 2

Note: The straight lines represent critical bounds at 5\% significance level. 

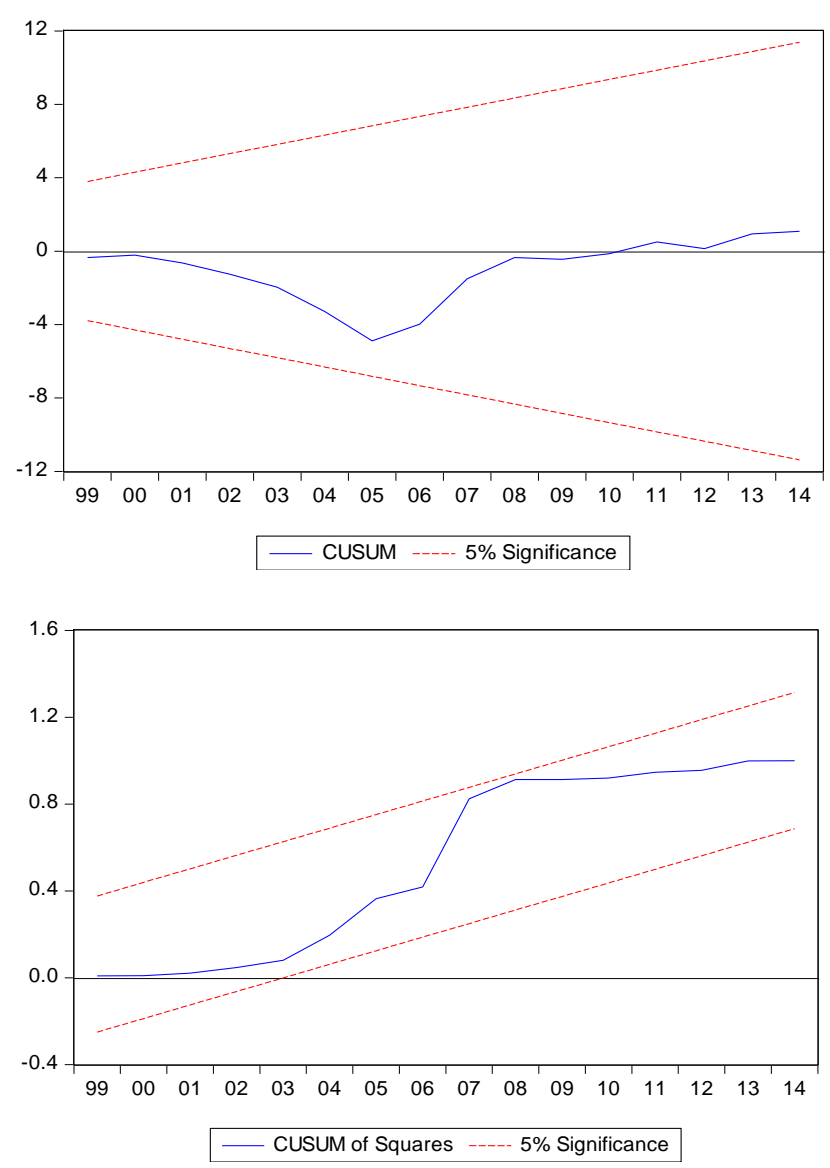

Figure 6. Plot of CUSUM and CUSUM Square of Model 3

Note: The straight lines represent critical bounds at 5\% significance level.

\section{Summary Results from Three Models}

Table 3 exhibit the summary results for the three models discussed above. The GDP had been set as the dependent variable for three models in the long-run analysis. Overall, it has verified a positive relationship between energy consumption and GDP for three models. In addition, total export showed a positive relationship with GDP for Model 2 and Model 3. However, a significant negative relationship is observed between carbon dioxide emission and GDP in Model 2. Lastly, crisis variables indicated a positive relationship with GDP when integrated with all variables in Model 3.

Table 3. Results from Three Models

\begin{tabular}{ccccc}
\hline es & Variabl & Model 1 & Model 2 & Model 3 \\
\hline LEC $_{\mathbf{t}}$ & $4.5910^{* *}$ & $3.1310^{* * *}$ & $2.8073^{* *}$ \\
& $(0.0072)$ & $(0.0002)$ & $(0.0007)$ \\
LCO $_{\mathbf{t}}$ & - & $-1.6965^{* *}$ & -1.3820 \\
& & $(0.0354)$ & $(0.0756)$ \\
LTE $_{\mathbf{t}}$ & - & $0.5126^{* *}$ & $0.5095^{* *}$ \\
& $\mathbf{D}_{\mathbf{m}}$ & - & $(0.0000)$ & $(0.0000)$ \\
& & - & $0.6040^{* *}$ \\
\hline
\end{tabular}


Notes: Asterisks ** shows the statistically significance at 5 percent level. $\mathrm{D}_{\mathrm{m}}$ stands for crisis variables.

\section{Conclusion and Policy Recommendations}

This study has explored the relationships between energy consumption and economic growth of China from 1971 to 2014. This study had incorporated three models by examining the impact of variables on economic growth after integrated with the other variables. Model 1 only examine the relationship between energy consumption and economic growth; Model 2 investigates the relationships between energy consumption, carbon dioxide emission, total export, and economic growth; Model 3 examined the relationships between variables mentioned in Model 2 and integrated the crisis variables which represent the economic crisis occur during the study periods.

Overall findings had confirmed there is a long-run relationship exist between energy consumption, carbon dioxide emission, total export, and economic growth. The investigation of long-run relationships for three models indicated energy consumption is positively affected economic growth of China. The results of a positive relationship between energy consumption and economic growth which supported the early studies that found similar results conducted by Lean and Smyth (2010a), Apergis and Payne (2010), Ozturk and Acaravci (2010), Shahbaz and Lean (2012), and Ucan et al. (2014). However, it should worth to note that the problem of scarcity of non-renewable resources and serious environmental crisis which eventually affect the people's health and environment quality if China government did not take appropriate measure in energy consumption. A positive relationship is observed between the total export and economic growth of China. To a certain extent, an increase of total export will induce economic growth, but it also stimulates industrialization which requires more resources for production needs. If the situation out of the control, there will be overconsumption of energy and raising the problem of air pollution in China due to the air pollutant emission. This study had considered the role of carbon dioxide emission in effect the economic growth. Hence, the results revealed carbon dioxide emission is negatively related to economic growth which supported the view of literature done by Ozturk and Acaravci (2010) and Tiwari et al. (2013) who found similar results. An increase of carbon dioxide emission due to the large scale of industrialization to meet the needs of production leading to an increase in carbon dioxide emission. When under a situation of the excess of carbon dioxide emission, the government will require to rising of public expenditure on healthcare and action in reducing carbon dioxide emission in the country which causes an unbalance of allocation spending and affect economic growth either directly and indirectly. By considering the role of economic crisis, it is interesting to show a positive relationship between crisis and economic growth, which means China's economy growing up without or less be influenced by the economic crisis.

In term of policy recommendation, policymakers of China should also focus on environmental issues rather only on economic growth. On the other words, China government should implement a balance environmental-economic policy. Several polices should also need to be introduced against serious environmental issues especially air pollution due to excessive carbon dioxide emission. For instance, carbon emission tax can be imposed on the 
industry and household who are emitting the carbon dioxide over a certain limit. Meanwhile, this is requiring some monitoring technologies in tracking on this matter and introduce the tax structure of carbon emission. Besides that, a popularization of using renewable energy in daily life such as a configuring panel of solar energy for power generation and hybrid or electrical generated transportation. Some subsidy policy can be implemented to encourage people to purchase clean technology which eventually abandoned non-renewable energy progressively. In addition, it very much needs strict enforcement of punishment for illicit logging of forests, promotes reserve forests policy such as planting trees and establish national parks.

Although this study adding a new evident link between energy consumption and economic growth of China to the existing literature. But this study cannot have an exemption from limitation. The major limitation of this study is that bounded with energy consumption, carbon dioxide emission, and total export only. But the reality of energy consumption may exist in the various form of indicators which not only limit to $\mathrm{kg}$ of oil equivalent. In the sense that, the future study suggested to use different types of energy consumption indicators in order to achieve a comprehensive understanding and give an insight on policy recommendation. And, future literature encouraged to add-in other pollution indicators instead of only carbon dioxide emission. Lastly, the study is strongly recommended to examine the impact of health expenditure to extend the links of the nexus between energy consumption, environmental quality, and economic growth in China.

\section{References}

Al-Mulali, U., Ozturk, I., \& Lean, H. H. (2015). The Influence of Economic Growth, Urbanization, Trade Openness, Financial Development and Renewable Energy on Pollution in Europe. Natural Hazards, 79(1), 621-644. https://doi.org/10.1007/s11069-015-1865-9

Alper, A., Hakan, K., Oguz, O., \& Onur, G. (2013). Energy Consumption and Economic Growth: Evidence from Micro Data. ASBBS Proceedings, 20(1), 280-288.

Antonakakis, N., \& Chatziantoniou, I. (2017). Energy Consumption, $\mathrm{CO}_{2}$ Emissions, And Economic Growth: An Ethical Dilemma. Renewable and Sustainable Energy Reviews, 68, 808-824. https://doi.org/10.1016/j.rser.2016.09.105

Apergis, N., \& Payne, J. E. (2010). Energy Consumption and Growth in South America: Evidence from a Panel Error Correction Model. Energy Economic, 32(6), 1421-1426. https://doi.org/10.1016/j.eneco.2010.04.006

Ayeche, M. B., Barhoumi, M., \& Hammas, M. A. (2016). Causal Linkage Between Economic Growth, Financial Development, Trade Openness and CO2 Emissions in European Countries. American Journal of Environmental Engineering, 6(4), 110-122.

Belke, A., Dreger, C., \& Haan, F. (2011). Energy Consumption and Economic Growth: New Insights into The Cointegration Relationship. Energy Economic, 33(5), 782-789. https://doi.org/10.1016/j.eneco.2011.02.005

Cui, H. Y. (2016). China's Economic Growth and Energy Consumption. International Journal 
of Energy Economics and Policy, 6(2), 349-355.

Dickey, D. A., \& Fuller, W. A. (1979). Distribution of The Estimators for Autoregressive Time Series with A Unit Root. Journal of American Statistical Association, 74(366), 427-431. https://doi.org/10.2307/2286348

Enerdata. (2018). Rise in Global Energy-Related $\mathrm{CO}_{2}$ Emissions in 2017. Retrieved from https://www.enerdata.net/publications/executive-briefing/global-increase-co2-emissions-2017 .html

Gujarati, D. N., \& Porter, D. C. (2009). Basic Econometrics (5 $5^{\text {th }}$ ed.). New York, NY: McGraw-Hill.

Hays, J. (2015). Environmental Problems in China, Pollution and Health Problems. Facts and Details. Retrieved from http://factsanddetails.com/china/cat10/sub66/item394.html

Iş1k, C., \& Shahbaz, M. (2015). Energy Consumption and Economic Growth: A Panel Data Approach to OECD Countries. International Journal of Energy Science, 5(1), 1-5. https://doi.org/10.12783/ijes.2015.0501.01

Lean, H. H., \& Smyth, R. (2010a). CO2 Emissions, Electricity Consumption and Output in ASEAN. Applied Energy, 87(6), 1858-1864. https://doi.org/10.1016/j.apenergy.2010.02.003

Lean, H. H., \& Smyth, R. (2010b). On The Dynamics of Aggregate Output, Electricity Consumption and Exports in Malaysia: Evidence from Multivariate Granger Causality Tests. Applied Energy, 87(6), 1963-1971. https://doi.org/10.1016/j.apenergy.2009.11.017

Lean, H. H., \& Smyth, R. (2010c). Multivariate Granger Causality Between Electricity Generation, Exports, Prices and GDP in Malaysia. Energy, 35(9), 3640-3648. https://doi.org/10.1016/j.energy.2010.05.008

Lee, C. C., \& Chang, C. P. (2005). Structural Breaks, Energy Consumption, And Economic Growth Revisited: Evidence from Taiwan. Energy Economics, 27(6), 857-872. https://doi.org/10.1016/j.eneco.2005.08.003

Liang, Y. G., McIntosh, W., \& Webb, J. R. (1995). Intertemporal Changes in The Riskiness of REITs. The Journal of Real Estate Research, 10(4), 427-443. https://doi.org/10.1007/BF01096944

Lotz, R. I. (2016). The Impact of Renewable Energy Consumption to Economic Welfare: A Panel Data Application. Energy Economics, 53, 58-63.

Narayan, P. K., \& Smyth, R. (2005). Electricity Consumption, Employment and Real Income in Australia Evidence from Multivariate Granger Causality Tests. Energy Policy, 33(9), 1109-1116. https://doi.org/10.1016/j.enpol.2003.11.010

Ozturk, I., \& Acaravci, A. (2010). $\mathrm{CO}_{2}$ Emissions, Energy Consumption and Economic Growth in Turkey. Renewable and Sustainable Energy Reviews, 14(9), 3220-3225. https://doi.org/10.1016/j.rser.2010.07.005 
Payne, J. E. (2009). On The Dynamics of Energy Consumption and Employment In Illinois. The Journal of Regional Analysis and Policy, 39(2), 126-130.

Pesaran, M. H., Shin, Y., \& Smith, R. (2001). Bounds Testing Approaches to The Analysis of Level Relationships. Journal of Applied Econometrics 16, 289-326. https://doi.org/10.1002/jae.616

Phillips, P., \& Perron, P. (1988). Testing for a Unit Root in Time Series Regression. Biometrica 75(2), 335-346. https://doi.org/10.1093/biomet/75.2.335

Shahbaz, M., \& Lean, H. H. (2012). The Dynamics of Electricity Consumption and Economic Growth: A Revisit Study of Their Causality in Pakistan. Energy, 39(1), 146-153. https://doi.org/10.1016/j.energy.2012.01.048

Shahbaz, M., Khan, S., \& Tahir, M. I. (2013). The Dynamic Links Between Energy Consumption, Economic Growth, Financial Development and Trade in China: Fresh Evidence from Multivariate Framework Analysis. Energy economics, 40, 8-21. https://doi.org/10.1016/j.eneco.2013.06.006

Shahbaz, M., Khraief, N., Uddin, G. S., \& Ozturk, I. (2014). Environmental Kuznets Curve in an Open Economy: A Bounds Testing and Causality Analysis for Tunisia. Renewable and Sustainable Energy Reviews, 34, 325-336. https://doi.org/10.1016/j.rser.2014.03.022

Shahbaz, M., Lean, H. H., \& Farooq, A. (2013). Natural Gas Consumption and Economic Growth in Pakistan. Renewable and Sustainable Energy Reviews, 18, 87-94. https://doi.org/10.1016/j.rser.2012.09.029

Shahbaz, M., Tang, C. F., \& Shabbir, M. S. (2011). Electricity Consumption and Economic Growth Nexus in Portugal Using Cointegration and Causality Approaches. Energy policy, 39(6), 3529-3536. https://doi.org/10.1016/j.enpol.2011.03.052

Shahbaz, M., Zeshan, M., \& Afza, T. (2012). Is Energy Consumption Effective to Spur Economic Growth in Pakistan? New Evidence from Bounds Test to Level Relationships and Granger Causality Tests. Economic Modelling, 29(6), 2310-2319. https://doi.org/10.1016/j.econmod.2012.06.027

Soytas, U., \& Sari, R. (2003). Energy Consumption and GDP: Causality Relationship in G-7 Countries and Emerging Markets. Energy Economics, 25, 33-37. https://doi.org/10.1016/S0140-9883(02)00009-9

Tiwari, A. K. (2011). Energy Consumption, $\mathrm{CO}_{2}$ Emissions and Economic Growth: A Revisit of the Evidence from India. Journal of International Business and Economy, 12(1), 85-122. https://doi.org/10.2478/v10033-011-0019-6

Tiwari, A. K., Shahbaz, M., \& Hye, Q. M. A. (2013). The Environmental Kuznets Curve and The Role of Coal Consumption in India: Cointegration and Causality Analysis in an Open Economy. Renewable and Sustainable Energy Reviews, 18, 519-527. https://doi.org/10.1016/j.rser.2012.10.031 


\section{Macrothink}

Journal of Public Administration and Governance ISSN 2161-7104 2020, Vol. 10, No. 2

Ucan, O., Aricioglu, E., \& Yucel, F. (2014). Energy Consumption and Economic Growth Nexus: Evidence from Developed Countries in Europe. International Journal of Energy Economics and Policy, 4(3), 411-419.

Vlahinić-Dizdarević, N., \& Žiković, S. (2010). The Role of Energy in Economic Growth: The Case of Croatia. Zbornik radova Ekonomskog fakulteta u Rijeci: časopis zaekonomsku teoriju i praksu, 28(1), 35-60.

World Bank (2018). World Development Indicators.

Yang, H. Y. (2000). A Note on the Casual Relationship Between Energy and GDP in Taiwan. Energy Economics, 22(3), 309-317. https://doi.org/10.1016/S0140-9883(99)00044-4

\section{Copyright Disclaimer}

Copyright for this article is retained by the author(s), with first publication rights granted to the journal.

This is an open-access article distributed under the terms and conditions of the Creative Commons Attribution license (http://creativecommons.org/licenses/by/4.0/). 